\title{
Judicial Activism In Criminal Case To Ensure The Human Rights Upholding (Study In State Court Of Semarang)
}

\author{
Wilmar Ibni Rusydan ${ }^{1}$, Umar Ma'ruf ${ }^{2}$, and Bambang Tri Bawono ${ }^{3}$
}

Abstract. The purpose of this study was to describe, assess, and analyze as to what the underlying factors in implementing the Judge on Judicial Activism practice in criminal cases in order to ensure the upholding of human rights, then any obstacles encountered and solutions that were presented.

This study uses a sociological juridical approach to research is descriptive analytical specifications. The data used are secondary data obtained through library research and primary data obtained through field research then analyzed qualitative use Progressive Legal Theory and Theory of Freedom and Discovery Law of Judge (Rechstvinding).

The results of this study are: 1) Judge's decision to apply for Judicial Activism in criminal cases at least consider several factors, including legal developments always follow people who move quickly, in addition to the Act or other regulations are not always equipped to solve a legal case concretely, and also some other factors; 2) Obstacles that arise in practice Judicial Activism in criminal cases are divided into two (2) factors, namely the internal source of personality and emotionality judges themselves, then external factors relating to the legal system of a country.

Keywords: Judicial Activism; Criminal Case; Judge; Human Rights.

\section{Introduction}

Justice is basically the implementation of the law, in terms of concrete demands rights or disputes or violations, the function performed by an entity by providing a binding decision and aimed to prevent vigilante (eigenrichting) . $^{4}$ The existence of the principle of independence of judges in examining and deciding the case and the absence of partisanship is a guarantee generates fair decision, and the judge in a case shall refer and apply legislation, sources and other sources of law (jurisprudence, customs, legal awareness, principles law) for any court decision based on a rule 5 .

Breaking the law is according to the first and last duty of a judge. Law as a tool, as a means, and output decision, should be able to bring about justice, order, tranquility, and others. Based on the legal relevance and purpose of the law, there are three functions of judges in applying the law, which merely apply the law as it is, find the law, and creates legal ${ }^{6}$.

\footnotetext{
${ }^{1}$ Students of Master of Law, Sultan Agung Islamic University, Semarang email: wilmrusyd@gmail.com

${ }^{2}$ Faculty of Law UNISSULA Semarang

${ }^{3}$ Faculty of Law UNISSULA Semarang

${ }^{4}$ Sunarto, 2014, Peran Aktif Hakim dalam Perkara Perdata, Jakarta: PrenadaMedia Group, p.62

${ }^{5}$ Ibid.

6 The Papers of Great Chief of Justice, Hakim Sebagai Pembaharu Hukum, Varia Pengadilan Magazine In Years To XXII Law No. 245 in January 2007, Jakarta, IKAHI, p. 8.
} 
The judge in the examine, hear and decide a case, first must use written law first, that legislation, but if the legislation was not sufficient and not appropriate to the issues in a case, the judge will seek and find itself ruling on the sources of law such as jurisprudence, doctrine, treaties, customary or unwritten law (living law) ${ }^{7}$. In addition, the judge in the hearing and deciding the case, free from the interference of society, the executive, and legislative branches. With its freedom, it is expected the judge can make a decision based on the applicable law and based on his belief that the fairest and provide benefits for the community".

In the tradition of any law, both civil law and common law, there is often a gap between the law of the development of society. This resulted in the emergence of the legal community needs to be responsive to be able to provide answers to the problems that arise. In a democratic life, the court became one of the targeted communities to bridge the gap between law and social reality ${ }^{8}$.

Departing from this, the concept of judicial activism is present. Judicial Activism is a philosophy of judicial decision-making, in which the judges base their deliberations on a new development or public policy is growing. Such considerations into landing him in deciding the case being dealt with for their new development or perhaps even earlier judgment contrary to the previous ruling ${ }^{9}$, Furthermore, Keenan D. Kmiec states that a judge can be regarded as a Judicial Activist when they are exercising its authority based on justice and human rights rather than "misuse of authority"10.

This study was conducted to determine how far the State Court of Semarang apply the Judicial Activism in criminal cases to ensure the upholding of human rights and what the underlying background of judges applying the Judicial Activism. In addition, this study conducted to determine the barriers to adoption of Judicial Activism in relation to the duties and authority of the judge.

\section{Research Methods}

To answer the problem to be studied, the approach taken by the authors is sociological juridical approach, because it is made by reviewing the laws and systematics are then applied to study a problem in society with the aim of getting the facts, to formulate the problem and find the root of the problem settlement ${ }^{11}$.

\footnotetext{
${ }^{7}$ Ahmad Rifai, 2014, Penemuan Hukum Oleh Hakim dalam Perspektif Hukum, Jakarta: Sinar Grafika, p. 6.

${ }^{8}$ Wicaksana Dramanda, 2014, Menggagas Penerapan Judicial Restraint di Mahkamah Konstitusi, Jurnal Konstitusi, Volume 11 number 4, p. 619

${ }^{9}$ E-learning.mahkamahagung.co.id. Training Module Training and Education Program Candidate JudgeNarrative Integrated General Court Judicial Activism. 2019. Translation of Black's Law Dictionary Eight Edition. Judicial Activism, n. A. A Philosophy of Judicial Decision making whereby Judges allow their personal views about public policy, among others factors, to guide their decisions, With the sugestion that aderents of this philosophy tend to find constitutional violations and are willing to ignore precedent.

${ }^{10}$ D. Keenan Kmiec, The Origin and Current Meanings of Judicial Activism, California law Review, Vol. 92.

5, October 2004, p. 1451.

${ }^{11}$ Burhan Ashshofa, 2001, Metode Penelitian Hukum, Jakarta: Rineka Cipta, p. 40
} 


\section{Research And Discussion}

\subsection{Judge Consideration of State Court of Semarang in Doing Judicial Activism on Criminal Case}

State Court of Semarang is one of the executing judicial authority in the general courts. The principal tasks of State Court of Semarang are as follows:

- Hear and resolve cases submitted to it in accordance with Act No. 48 of 2009 on Judicial Power.

- Carrying out the Case Administration and other Public Administration.

State Court of Semarang entered in the jurisdiction of the High Court in Central Java, with an area of approximately $371.52 \mathrm{~km}^{2}$ which consists of 16 (sixteen) districts and 177 (one hundred and seventy-seven) villages ${ }^{12}$. In addition, the State Court of Semarang is one of the court with qualification (class) specifically to the case $1 \mathrm{~A}$ of more than 2000 cases annually. More than 2000 criminal cases were divided into general, special criminal, civil, public, and special civil.

Authors see one of the Judges of the State Court of Semarang Dr. Eddy Parulian Siregar as a judge with full qualification for General Crimes, Special Criminal, Civil Works and Special Civil to discuss ongoing research that takes title judicial Activism the Rule of Criminal Case for Ensuring Human Rights.

Eddy during a career in State Court of Semarang said that they had made several judicial Activism and set forth in its decision due to consider the issue of human rights as something to be protected and to maintain a sense of justice in society ${ }^{13}$, For example, Eddy provide a copy of the criminal verdict number 340 / Pid.Sus / 2019 / PN SMG and the decision number 192 / Pid.B / 2016 / PN SMG.

Case number 340 / Pid.Sus / 2019 / PN SMG is a special criminal cases where the accused is charged under Section 122 letter a of Act No. 06 of 2011 About Immigration. In the process of the trial is known that the defendant is a foreign national who has been detected by PNS Immigration investigators before the case is declared complete and handed over to the prosecutor and to the court. Problems arise when the detention period of the defendant carried out by PNS Immigration Investigator equivalent period of detention. In consideration, the panel of judges chaired by Judge of Eddy wrote as follows:

Considering that from reports Staff the trial court and is associated with the defense of the accused, then the judges see the legal fact that the investigator investigators Immigration who left the defendant in immigration detention Semarang as a forceful measures that restrict the freedom and rights of life of the defendant;

\footnotetext{
${ }^{12}$ https://www.pn-

semarangkota.go.id/index.php?option=com content\&view=article\&id=1\&ltemid=48\&lang=id, Accessed on 6 November 2019

13 Interview with Judge of Eddy Parulian Siregar, State Court of Semarang, November 10, 2019 At 11:44 $\mathrm{pm}$
} 
Considering the question whether this care can be categorized as the detention of the defendant given the already limited freedom of the defendant and whether this care can be deducted from the sentence that will be imposed on the defendant;

Considering, since the fact of forceful measures against the freedom of the accused were placed in immigration detention, for the sake of justice and truth is the right of a defendant who has been restricted liberty in immigration detention, are entitled to a reduction of the length of the sentence imposed;

In its decision number 340 / Pid.Sus / 2019 / PN SMG, Judge of Eddy consider detention in immigration detention Semarang $1 \mathrm{~A}$ class equivalent general detention for substantially detention is a restriction of independence while pending the judicial process is complete. While in Article 22 paragraph (4) shall be that the period of arrest or detention is deducted entirely from the sentence imposed. To ensure the establishment of the Human Rights Council of Judges take into consideration the penalty imposed should be reduced entirely from arrest and detention, including detention in immigration detention

Meanwhile, case number 192 / Pid.B / 2016 / PN SMG is a matter of theft nominal value of the losses slightly (below Rp. 2.500.000,00), but the public prosecutor still take the case to the regular events. In its decision number 192 / Pid.B / 2016 / PN SMG, to find the exact value of the loss, then Chairman of the Council, namely Judge of Eddy local checks on its own initiative to some printing business in Semarang and the results obtained by these losses is far below the price indicted by the public prosecutor. Furthermore, under the terms of Judge found against the case should be filed with the rapid events in the form of a misdemeanor and decide that "Prosecution Unacceptable". In his judgment,

Considering that because of the differences between the prosecutor Public Prosecutor and the Legal Adviser of the price of the banners were stolen defendant, where it is associated with the shape and the way the accused should be charged, whether the event quickly shaped misdemeanor or with regular events with a criminal offense ordinary, which it is due to forceful measures, for example whether or not detention, the law for the sake of local assemblies examination by reviewing some of Printing Banner Printing Simongan among others, PT. Promos Indonesia Advertising, Digital Printing Success Jaya, as well as to the tax office and Advertising (the evidence brought to the printing company / office);

Considering, therefore if considered the provisions of Article 1 and Article 2 PERMA, then in case there do indictment with the offense of theft value of the goods or the money becomes the object of the case is not over Rp2.500.000,00 (two million five hundred thousand rupiah) then the case should be examined with a misdemeanor with a quick check with the event and can not be the sole judge of detention 
Broadly speaking, it can be seen from the example of the case in the District Court of Semarang above, that the Judge's decision that did Judicial Activism at least consider several factors, namely:

- Legal developments always follow people moving and rapidly evolving.

- Act or the regulations are not always equipped to solve a legal case concretely, because he is only a stage in the law-making process, thus empirically judge shall furnish in solving and finding solutions for its decision.

- Judge not merely mouth or funnel legislation.

- Judge in deciding the case shall explore, and understand the legal values and sense of justice in society.

- Judge in deciding the case be guided by the views of the scientific based independent, free, and responsible.

- Judges through the decisions expected to provide inspiration and innovation that led to the development of law, particularly in relation to the relationship between the state / government to the citizens of the governed.

- In the process of evidence in the trial, the judges look for the material truth, not just a formal truth. Especially for proof in principle is free but limited ${ }^{14}$.

\subsection{Implementation Barriers of Judicial Activism in Criminal Case if Anchored by Judge Duties and Authorities}

Eddy argued that if the judge is required to make the Judicial Activism, is not as easy as deciding the case is unusual, because there are internal factors and external factors which play a role. External factors, Eddy argue that in fact the outset Judge has limited authority and are bound by legislation so that its active role is very limited because Indonesia is adopting evidence based legislation negatively (negatief wettelijk bewijstheori). With the rigidity of the role of judges in the subject of official proof could lead to potential misconduct by law enforcement officers in the process of collecting evidence, which resulted in causing losses (violation of the right). The active role of judges in criminal justice is still very low due to the Criminal Procedure Code has not yet adopted rechtsvinding existing authority in the Judicial Power. With the enactment of the Criminal Procedure Code still, then the position of the judge was limited to the funnel of law.

Furthermore, is the resistance of the Internal factors Hakim. Basically the judge internal factors are factors derived from the personality and emotional of the judge himself. Judges like social scientists, can only seek to minimize emotion in every process of thinking, although it can not negate aspects of personality (emotional) is. This indicates that the personality of the judge was instrumental to the decision produced by the Judge.

\footnotetext{
${ }^{14}$ Interview with Judge of Eddy Parulian Siregar, State Court of Semarang, November 10, 2019 At 11:44 $\mathrm{pm}$
} 
Obstacles that arise in practice Judicial Activism both internal and external barriers can be addressed with the theory of judicial independence in judging. For example, within the constraints of internal factors, namely the factor of personality and emotionality judge, then the judge can not be blamed if it believes that the law is a set of laws and other written rules, and do not take more of a role by implementing Judicial Activism.

In contrast to the constraints of internal factors, external factors barriers to the implementation of the Judicial Activism is more difficult because it deals with the legal system. a judge unable to free themselves from the obligation to base decisions on Criminal Procedure or statutory provisions in force, it is of course somewhat at odds with the theory of progressive law where the law does not have to reflect itself as an institution that is final and rigid, but seen from its ability to serve mankind, Basically the theory rests on the independence of judges, a judge can not be forced to the view that the Judicial Activism is the best way to judge because it involves independence.

\section{Closing}

\subsection{Conclusion}

Based on the above discussion, the writer can draw the following conclusion:

- Judge's decision that does Judicial Activism in criminal cases at least consider several factors, namely:

- Legal developments always follow people moving and rapidly evolving.

- Act or the regulations are not always equipped to solve a legal case concretely, because he is only a stage in the law-making process, thus empirically judge shall furnish in solving and finding solutions for its decision.

- Judge not merely mouth or funnel legislation.

- Judge in deciding the case shall explore, and understand the legal values and sense of justice in society.

- Judge in deciding the case be guided by the views of the scientific based independent, free, and responsible.

- Judges through the decisions expected to provide inspiration and innovation that led to the development of law, particularly in relation to the relationship between the state / government to the citizens of the governed.

- In the process of evidence in the trial, the judges look for the material truth, not just a formal truth. Especially for proof in principle is free but limited.

- The Implementation Barrier of Judicial Activism in a criminal case can be divided into two (2) factors, namely:

Internal factors: Factors derived from the personality of the judge own. Judges can seek to minimize emotion in every process of thinking, although it can not negate aspects of personality (emotional) is. This indicates that the personality of the judge was instrumental to the decision produced by Judge 
External factors : Judge has limited authority and are bound by legislation so that its active role is very limited because Indonesia is adopting evidence based legislation negatively (negatief wettelijk bewijstheori). That is, the evidence used as the basis of sentencing are evidence mentioned in the Criminal Code. Then it becomes futile to judge if a normative belief an evidence not provided for in legislation. In fact, not only there, the interpretation of the extension which may be done by judges into something that can not stand alone in absolute if not followed by multiple verification. This occurs due to still strong tradition of Civil Law System, which still dominate the legal system in Indonesia.

\subsection{Suggestion}

Based on the above conclusions, the suggestions to the author to convey is:

- Suggested to the judge in a criminal case dropped to a case that the legal basis or unclear legal facts by law, do not just look at the normative, but must Judicial Activism to provide justice and protection of human rights.

- Suggested to the judge who still believes that the law is legislation alone so flexible, the judge not only become the mouthpiece of the law, but the judge should not hesitate to carry out a legal breakthrough, action contra, found the law and to establish the law, if deemed rule contained in the legislation concerned does not correspond to the sense of justice in society and protection of human rights.

\section{References}

[1] Ahmad Rifai, 2014, Penemuan Hukum Oleh Hakim Dalam Perspektif Hukum Progresif, Jakarta: Sinar Grafika

[2] Burhan Ashshofa, 2001, Metode Penelitian Hukum, Jakarta: Rineka Cipta

[3] Satjipto Rahardjo, 2006, Hukum Progresif Sebagai Dasar Pembangunan IImu Hukum, dalam buku Menggagas Hukum Progresif Indonesia, Semarang: Kerjasama Pustaka Pelajar, IAIN Walisongo and Legal Studies Doctoral Program UNDIP

[4] Sunarto, 2014, Peran Aktif Hakim dalam Perkara Perdata, Jakarta: PrenadaMedia Group

[5] Zainal Abidin Farid, Hukum Pidana I, 2007, Jakarta: Sinar Grafika

\section{Journals and Articles:}

[1] D. Keenan Kmiec, 2004, The Origin and Current Meanings of Judicial Activism, California law Review, Vol. 92. 5, October

[2] J. Djohansjah, the Supreme Court Reform Towards Independence Power Kahakiman, in Luhut Pangaribuan. "Lay Judges and Judges Ad Hoc, Theoretical Studies Regarding the Indonesian Criminal Justice System", (Jakarta: Faculty of Graduate Studies, University of Indonesia, 2009),

[3] Pan Mohamad Faiz, Title Restraint VS Judicial Activism, Journal Constitution, No. 130, December 2017 
Jurnal Daulat Hukum: Volume 2 Issue 4, December 2019 : 477 - 484

[4] Wicaksana Dramanda, Promoting Implementation of Judicial Restraint in the Constitutional Court, Journal Constitution, Volume 11 number 4. 2014 